\title{
PRISÃO ANTES DO TRÂNSITO EM JULGADO: UMA PRAGMÁTICA DOS SENTIDOS
}

\author{
PRISON BEFORE RES JUDICATA: \\ A PRAGMATICS OF MEANING
}

\section{LA PRISION ANTES DEL TRÁNSITO EM JUZGADO DE LA CONDENA PENAL: UNA PRAGMÁTICA DEL SENTIDO}

\author{
Cecília Caballero Lois \\ https://orcid.org/0000-0002-1907-8532 / http://lattes.cnpq.br/7602302438627219 / cecilialois@gmail.com \\ Universidade Federal do Rio de Janeiro, UFRJ. \\ Rio de Janeiro, RJ, Brasil. \\ QUINTINO LoPES CASTRO TAVARES \\ https://orcid.org/0000-0003-0235-7022 / http://lattes.cnpq.br/0808307095635730 / quintinotavares@id.uff.br \\ Universidade Federal Fluminense, UFF. \\ Niterói, RJ, Brasil.
}

\begin{abstract}
RESUMO
Neste artigo, analisamos o entendimento formado a partir do julgamento do Habeas Corpus $N^{\circ} 126.292 / \mathrm{SP}$ pelo Supremo Tribunal Federal, conforme o qual o princípio da presunção de inocência não proíbe o cumprimento antecipado da pena estabelecida pelo tribunal de apelação, antes mesmo do trânsito em julgado. Argumentamos que essa resultante interpretação é legitimamente possível face a uma pragmática do texto. Mas a compreensão precisa se conformar a certas condições, de modo a assegurar a integridade do sistema jurídico, tendo em conta que se baseia na enciclopédia, conforme o contexto histórico e sociológico em que se insere. Por outro lado, o texto por si só possibilita um número ilimitado de interpretações, mas a Constituição, por ser um texto público, em que o sentido está conformado pelas circunstâncias de anunciação e de enunciação, requer uma interpretação que amplia sua criação e finalidade. Por fim, a interpretação constitucional somente é possível sob a base de uma interpretação sistemática, cujo resultado consequente não pode ignorar os sentidos produzidos pelo sistema como um todo.
\end{abstract}

Palavras-chave: Hermenêutica constitucional; Habeas Corpus 126.292/SP; Interpretação jurídica; Pragmática textual; Semiótica.

\begin{abstract}
In this paper we analyze the construction formed by the Brazilian Supreme Court in the judgment of Great Writ $\mathrm{N}^{\circ}$ 126.292/SP according to which the principle of the presumption of innocence provided in article $5^{\circ}$, LVII, of the Brazilian Constitution does not prohibit the early enforcement of the criminal condemnation by the appellate court, before the force of res judicata. We argue that that resultant interpretation is legitimately possible according to a textual pragmatics. But that understanding needs to conform to some conditions in order to secure the integrity of the legal system, considering that it's based on the encyclopedia, within a sociological and historical framework. In order hand, the text itself enables an unlimited number of interpretations, but the Constitution, as a public text, in which the meaning is configured by the circumstances of annunciation and enunciation, demands an interpretation that magnifies its creation and finality. Lastly, the constitutional interpretation only is possible on the systematic interpretation of the Law, and the outcome of which cannot ignore the meanings produced by the whole system.
\end{abstract}

Keywords: Constitutional hermeneutics; Great Writ 126,292/SP; Legal interpretation; Semiotics; Textual pragmatics. 


\section{RESUMEN}

En este artículo, analizamos el entendimiento formado a partir del juicio del Habeas Corpus $N^{\circ}$ 126.292/SP por el Supremo Tribunal Federal brasileño, según el cual el principio de la presunción de inocencia no prohíbe el cumplimiento anticipado de la condena penal por el tribunal de apelación, antes del tránsito en juzgado. Sostenemos que esa interpretación resultante es legítimamente posible según una pragmática del texto. Pero la comprensión necesita ajustarse a ciertas condiciones para asegurar la integridad del sistema jurídico, considerando que está basado en la enciclopedia, conforme el contexto histórico y sociológico en que se inserta. Por otro lado, el texto por sí solo posibilita un número ilimitado de interpretaciones, pero la Constitución, por ser un texto público, en el que el significado está configurado por las circunstancias de anunciación y de enunciación, requiere una interpretación que magnifica su creación y finalidad. Por último, la interpretación constitucional sólo es posible bajo la base de una interpretación sistemática, cuyo resultado consecuente no puede ignorar los sentidos producidos por el sistema como un todo.

Palabras clave: Hermenéutica Constitucional; Habeas Corpus 126.292/SP; Interpretación Jurídica; Pragmática Textual; Semiótica.

\section{SUMÁRIO}

INTRODUÇAO; 1 A NECESSIDADE DE UMA INTERPRETAÇÃO SISTEMÁTICA DA CONSTITUIÇÃO; 20 TEXTO DA LEI E A “VONTADE” INTERPRETATIVA; 3 HC 126.292/SP: PRISÃO APÓS SEGUNDA INSTÂNCIA; 3.1 A literalidade do princípio: presunção de não-culpabilidade; 3.20 ativismo da esperança antecipada da pena; 4 A PRAGMÁTICA DO TEXTO NO HC 126.292 E SUA LIMITAÇÃO; CONCLUSÃO; REFERÊNCIAS.

\section{INTRODUÇÃO}

Em 17 de fevereiro de 2016, no julgamento do Habeas Corpus n 126.292/SP, o Supremo Tribunal Federal mudou seu entendimento acerca do sentido interpretativo do princípio da presunção de inocência ou de não-culpabilidade, passando a entender que a execução antecipada da pena, após o acórdão decisório do recurso ordinário de apelação, mesmo antes do trânsito em julgado da sentença, não contraria a Constituição.

Neste artigo analisamos os principais fundamentos daquela decisão, tomando em conta principalmente os votos favoráveis ao cumprimento antecipado da pena, especialmente os votos do Ministro-relator Teori Zavascki e do Ministro Barroso. Trata-se, entretanto, de uma análise que busca enfatizar os aspectos pragmáticos dessa leitura do princípio constitucional da presunção de não-culpabilidade, com vista a demonstrar que não se trata de uma interpretação absurda, cujo sentido não seja possível encontrar no texto normativo. Em segundo lugar, ressaltamos alguns aspectos na decisão que contrariam não só a tradição interpretativa do princípio em questão, mas também ignoram por vezes o fato de que toda a interpretação é direcionada para um auditório, um outro, no caso, uma comunidade cuja pragmática exige que seja tomada em conta no diálogo interpretativo, sob pena de um solipsismo decisório e extravagância interpretativa. 
Apesar do reconhecimento válido de uma pragmática do texto constitucional, que permite extrair aquilo que o texto não diz explicitamente, mas dá sinais, implica ou implicita, é relevante salientar os limites dessa interpretação, cuja legitimidade não depende exclusivamente da vontade do intérprete, mas deve considerar, por se tratar da leitura de um texto público, das condições impostas pelo próprio autor do texto, na hipótese constitucional, pelo poder constituinte (empírica ou abstratamente considerada), bem como os significados históricos e sociologicamente considerados.

Face a uma pragmática do texto constitucional, em que não se pode controlar o valor que serve de fundamentação, a interpretação deve tomar como base a forma dialógica, cuja existência depende de um outro, que escuta, confere sentido, que corrige a racionalidade da justificação, etc. Para nós, portanto, uma pragmática interpretativa que implica um sentido ampliado do texto e seu contexto, a depender, além do enunciado, de quem escreveu, de quem lê, e das circunstâncias de anunciação e enunciação. Uma leitura que não só leva em conta as possibilidades do texto, mas também a quem é endereçada, a que se aplica e as expectativas interpretativas criadas e suas consequências, conforme o background knowledge permitido pela enciclopédia.

Por fim, sob o pressuposto de que só é possível uma interpretação jurídica sistemática, fazemos a confrontação entre os limites da nova leitura conferida ao princípio constitucional em questão com os dispositivos infraconstitucionais, arts. 105 e 107 da Lei de Execução Penal e art. 283 do Código de Processo Penal, que influem para um entendimento diverso do quanto estabelecido na decisão do Supremo Tribunal, cuja conformidade interpretativa deve ser ajustada.

\section{A NECESSIDADE DE UMA INTERPRETAÇÃO SISTEMÁTICA DA CONSTITUIÇÃO}

Essa desenfreada vocação à substituição de justiça por vingança denuncia aquela que em outra ocasião referi como estirpe dos torpes delinquentes enrustidos que, impunemente, sentam à nossa mesa, como se fossem homens de bem.

Eros Grau

Vista a Constituição sob a perspectiva de um texto harmônico, da qual depende toda a coerência do sistema e, consequentemente, da qual depende o sentido de todas as demais 
normas (infraconstitucionais), parece-nos legitimamente possível a identificação de uma pluralidade de topics ${ }^{1}$, ainda que incidente sobre um mesmo princípio ou fundamento.

$\mathrm{Na}$ perspectiva de uma semiótica textual, entre os limites do que se pode cunhar como uma pragmática "feliz" ou "infeliz", entendemos que a limitação interpretativa deve-se dar por meio do topic ${ }^{2}$ ou tema, que exercerá a função de limitar e estabelecer as condições de coerência do texto constitucional ${ }^{3}$. Por meio do topic, portanto, o intérprete da Constituição encontra condições para frear a ilimitada potencialidade da interpretação.

Porém, é preciso que esses topics possam coexistir em harmonia, sob pena de colapsar a congruência do sistema, uma vez que a interpretação de uma norma é, direta ou obliquamente, a do sistema inteiro, ou seja, "a interpretação jurídica é sistemática ou não é interpretação" (itálico no original) ${ }^{4}$.

É que a leitura da Constituição, de acordo com a enciclopédia em vigor, não implica uma interpretação apenas do texto constitucional em si, mas do sistema jurídico como um todo e das implicações práticas na vida das pessoas. Neste sentido, convém de antemão esclarecer o conceito de enciclopédia, face à sua importância no contexto de limitação da liberdade interpretativa, definido como esse horizonte ampliado de conhecimento ao qual nos referimos de modo a fazer sentido para o outro. Na hipótese, a enciclopédia constitucional representa esse conjunto de registros interpretativos ao qual nos referimos e do qual nos servimos para fundamentar as nossas interpretações.

Por conseguinte, no caso do Habeas Corpus $n^{\circ} 126.292 /$ SP (HC 126.292) ${ }^{5}$, ainda que se admita o resultado do topic enaltecido no voto vencedor, isto é, de que a prisão em segunda instância, antes do trânsito em julgado, não ofende o princípio da presunção de nãoculpabilidade, deverá ser coerente com os demais topics decorrentes do conjunto da obra (o sistema normativo vigente). Neste sentido, não se pode olvidar que essa afirmativa da prisão

\footnotetext{
1 ECO, Umberto. Lector in fabula: a cooperação interpretativa nos textos narrativos. São Paulo: Perspectiva, 2011. p. 4.

2 Quanto à escolha do termo topic, "cumpre esclarecer por que resolvemos empregar um termo inglês (outrossim cunhado na terminologia retórica grega) e não recorremos, ao invés, a |tema|, que parece servir perfeitamente para ao [sic] escopo. De fato, não haveria dificuldades em usar indiferentemente tema e topic, e às vezes o faremos, se não fosse que o termo | temal corre o risco de assumir também outras acepções”. ECO, Umberto. Lector in fabula: a cooperação interpretativa nos textos narrativos. São Paulo: Perspectiva, 2011. p. 71.

3 ECO, Umberto. Lector in fabula: a cooperação interpretativa nos textos narrativos. São Paulo: Perspectiva, 2011. p. 72.

${ }^{4}$ FREITAS, Juarez. A interpretação sistemática do direito. 5. ed. São Paulo: Malheiros, 2010. p. 76.

${ }^{5}$ BRASIL. Supremo Tribunal Federal. Habeas Corpus $n^{\circ} 126.292 / S P$. Tribunal Pleno, Rel. Min. Teori Zavascki. Brasília, DF, julgado 17 fev. 2016, DJe-100, 17 mai. 2016. Disponível em: < http://portal.stf.jus.br/processos/downloadPeca. asp?id=311159272\&ext=.pdf >. Acesso em 30 mar. 2018.
} 
após decisão de segunda instância traz a ameaça latente do sentido que se pretende aferir de outros textos normativos infraconstitucionais.

Nem se discute, na hipótese, a denominação do princípio constitucional, se presunção de inocência ou de não-culpabilidade, mas tanto a decisão que aceita a possibilidade de cumprimento da pena após o segundo grau, como a que entende-o possível somente após o trânsito em julgado da sentença condenatória, tem como efeito, conforme o caso, uma declaração incidenter tantum de (in)constitucionalidade, por exemplo, do art. 283 do Código de Processo Penal (CPP) ${ }^{6}$ e dos arts. $105^{7}$ e $107^{8}$ da Lei de Execução Penal (LEP) ${ }^{9}$.

Por um lado, com relação ao tema previsto no princípio da presunção de nãoculpabilidade, há uma espécie de segredo, um prenúncio, quanto à possibilidade de execução da pena antes do trânsito em julgado. 0 art. $5^{\circ}$, LVII, da Constituição da República Federativa do Brasil (CF/88) $)^{10}$, traz no seu bojo uma estrutura ideológica que oculta a anunciação direta do seu texto, posto que, não obstante a forma tradicional de se enunciar o princípio da presunção de inocência, na expressão "ninguém será considerado culpado" tem em si próprio uma "armação", guardada em filigrana na estrutura ideológica do texto, que permite juízos axiológicos diversos, conforme a investida pró ou contra a antecipação da prisão ${ }^{11}$.

Por outro lado, visto que "os meios e os fins somente são justificáveis uns pelos outros"12, a aplicação dos 105 e 107 da LEP choca de frente com a interpretação que entende plausível, senão obrigatório, o cumprimento da pena antes do trânsito em julgado ${ }^{13}$. Até mesmo

\footnotetext{
${ }^{6}$ BRASIL. Decreto-Lei no 3.869 de 3 de outubro de 1941. Código de Processo Penal. In: Diário Oficial da República Federativa do Brasil, Brasília, DF, 13 out. 1941. Disponível em: < http://www.planalto.gov.br/ccivil_03/decreto-lei/Del3689Compilado.htm >. Acesso em: 31 mar. 2018.

${ }^{7}$ Art. 105. Transitando em julgado a sentença que aplicar pena privativa de liberdade, se o réu estiver ou vier a ser preso, o Juiz ordenará a expedição de guia de recolhimento para a execução.

8 Art. 107. Ninguém será recolhido, para cumprimento de pena privativa de liberdade, sem a guia expedida pela autoridade judiciária.

9 BRASIL. Lei $n^{\circ} 7.210$ de 11 de julho de 1984. Institui a Lei de Execução Penal. In: Diário Oficial da República Federativa do Brasil, Brasília, DF, 13 de jul. 1984. Disponível em: < http://www.planalto.gov.br/ccivil_03/leis/l7210.htm >. Acesso em: 2 abr. 2018.

10 BRASIL. Constituição da República Federativa do Brasil, 1988. Disponível em: < http://www.planalto.gov.br/ccivil_03/constituicao/constituicaocompilado.htm >. Acesso em: 30 mar. 2018.

11 Cf. ECO, Umberto. Lector in fabula: a cooperação interpretativa nos textos narrativos. São Paulo: Perspectiva, 2011. p. 153.

12 FREITAS, Juarez. A interpretação sistemática do direito. 5. ed. São Paulo: Malheiros, 2010. p. 78.

${ }^{13}$ Cf. BRASIL. Supremo Tribunal Federal. Habeas Corpus $n^{\circ}$ 84.078/MG. Tribunal Pleno, Rel. Min. Eros Grau. Brasília, DF, DJe-035, julgado em 05 fev. 2009, publicado 26 fev. 2010, Ementário no 2391-5, p. 1048-1213. Disponível em: < http://redir.stf.jus.br/paginadorpub/paginador.jsp?docTP=AC\&docID=608531 >. Acesso em 30 mar. 2018. p. 1.126 .
} 
no julgamento do HC $126.292^{14}$, o Ministro Edson Fachin reconheceu que os dispositivos da LEP levam a entender que a execução da pena só deve começar depois de esgotados todos os recursos. Consequência idêntica que se extrai também do Código de Processo Penal Militar $(\text { CPPM })^{15}$ que, apesar da excepcionalidade do seu âmbito, estabelece no art. 592 que "somente depois de passada em julgado será exequível a sentença” ${ }^{16}$.

A propósito, nem mesmo José Ribas Vieira e Ranieri Resende, ao admitirem "com clareza a validade convencional da decisão" e o fato de que não parece haver precedentes na Convenção Americana sobre Direitos Humanos (CADH) que condicione o início da execução da pena ao trânsito em julgado da sentença, deixaram de reconhecer que "o norte hermenêutico positivado no artigo 29.b, da CADH" é pela norma mais favorável ao acusado, conforme o princípio pro homine $e^{17}$.

\section{O TEXTO DA LEI E A “VONTADE” INTERPRETATIVA}

As respostas em torno do tema podem ser analisadas sob a tradicional diferença entre o espírito da lei e o sentido do texto. No fundo, a controvérsia que, a partir da segunda metade do século XIX, coloca em disputa objetivistas e subjetivistas, que em termos hermenêuticos se resume na resposta à questão da vontade que deve prevalecer: a do texto ou a do legislador ${ }^{18}$ ?

\footnotetext{
14 BRASIL. Supremo Tribunal Federal. Habeas Corpus $n^{\circ}$ 126.292/SP. Tribunal Pleno, Rel. Min. Teori Zavascki. Brasília, DF, julgado 17 fev. 2016, DJe-100, 17 mai. 2016. Disponível em: < http://portal.stf.jus.br/processos/downloadPeca.asp?id=311159272\&ext=.pdf >. Acesso em 30 mar. 2018. p. 24. Note, ainda, que todas as citações às páginas deste HC se referem doravante ao Inteiro Teor do Acórdão, ainda que não se mencione.

15 BRASIL. Decreto-Lei n 1.002 de 21 de outubro de 1969. Código de Processo Penal Militar. In: Diário Oficial da República Federativa do Brasil, Brasília, DF, 21 out. 1969. Disponível em: < http://www.planalto.gov.br/ccivil_03/decreto-lei/Del1002.htm >.Acesso em: 31 mar. 2018.

${ }_{16}$ Cf. BRASIL. Supremo Tribunal Federal. Medida Cautelar na Ação Declaratória de Constitucionalidade 44 DF. Tribunal Pleno, Rel. Min. Marco Aurélio. Brasília, DF, ATA 23/2018, divulgado 6 mar. 2018, DJe 43, publicado 7 mar. 2018, ADC 44 - MC. Inteiro Teor do Acórdão (Medida Cautelar). Disponível em: < http: //www.stf.jus.br/portal/processo/verProcessoPeca. asp?id=313832408\&tipoApp=.pdf >. Acesso em: 30 mar. 2018. p. 241.

17 VIEIRA, José Ribas; RESENDE, Ranieri Lima. Execução provisória da pena: causa para a corte interamericana de direitos humanos? In: VIEIRA, José Ribas; LACOMBE, Margarida; LEGALE, SIDDHARTA. Jurisdição constitucional e direito constitucional internacional. Belo Horizonte: Forum, 2016. p. 163177. ISBN 978-85-450-0196-6. Disponível em: < https://ssrn.com/abstract=3223966 >. Acesso em 30 ago. 2018. p. 177.

18 CAMARGO, Margarida Maria Lacombe. Hermenêutica e argumentação: uma contribuição ao estudo do direito. 3. ed. Rio de Janeiro: Renovar, 2003. p. 128.
} 
Assim, na sua concepção originária, os subjetivistas preferem tomar a lei como uma expressão da vontade do legislador e, portanto, a função da interpretação é buscar o valor significativo que esse poder, enquanto autor, pretendeu conferir ao texto. Interpretação portanto ex tunc da norma criada ${ }^{19}$. Todavia, a tese objetivista tem a sua razão de ser, uma vez que, face às transformações sociais, a simples aplicação ipsis litteris das leis antigas pode gerar um efeito perverso. Assim, é neste sentido que M. Lacombe entende que, em conta de não se perder a coerência e unidade da ordem jurídica, deve-se ajustar as antigas leis (vigentes) à atualidade de sua aplicação, de modo a se constituir num corpus "coerente e harmônico de interpretação, dando ênfase aos elementos teleológico e axiológico da ordem jurídica"20.

Por esta razão, no século XX, o sentido do texto acaba por predominar, posto que, na sua expressão textual, não só diz o que está escrito, mas pode inclusive dizer mais do que o seu autor pensava ou planejava, garantindo-se válida por ela mesma. Assim, por sua textualidade, o texto pode funcionar como mecanismo protetor à voluntariedade do juiz mas deve, de qualquer forma, no momento de sua aplicação, ser atualizado no seu significado, tendo em vista as exigências de adaptação às mudanças sociais ${ }^{21}$.

$\mathrm{Na}$ verdade, mais do que a simples controvérsia em torno da vontade do autor e do sentido manifestado no texto, a questão jurídica envolve uma disputa política de poder, entre a autoridade do Legislativo e a do Judiciário:

$\mathrm{Na}$ luta então travada no âmbito da hermenêutica jurídica sobre a prevalência de uma ou de outra teoria de interpretação: subjetivista ou objetivista, [...] encontra-se subjacente uma luta política entre os poderes legislativo e judiciário. Em defesa do primeiro, argui-se pela democracia, no sentido de se privilegiar a vontade do legislador enquanto autêntico representante do povo; na segunda hipótese, disputa-se maior autonomia para o poder judiciário, que procura interpretar objetivamente a lei no momento de sua aplicação, a fim de fazer justiça para o caso concreto ${ }^{22}$.

Sob este viés, a questão está também relacionada à possibilidade ou não do Poder Judiciário conferir determinado sentido ao texto legal, diferente talvez daquela pretendida pelo autor originário, o Legislativo, mas possível, entretanto, à luz do significado atualizado da

\footnotetext{
${ }^{19}$ CAMARGO, Margarida Maria Lacombe. Hermenêutica e argumentação: uma contribuição ao estudo do direito. 3. ed. Rio de Janeiro: Renovar, 2003. p. 131.

${ }^{20}$ CAMARGO, Margarida Maria Lacombe. Hermenêutica e argumentação: uma contribuição ao estudo do direito. 3. ed. Rio de Janeiro: Renovar, 2003. p. 130.

${ }^{21}$ Cf. CAMARGO, Margarida Maria Lacombe. Hermenêutica e argumentação: uma contribuição ao estudo do direito. 3. ed. Rio de Janeiro: Renovar, 2003. p. 128-130.

22 CAMARGO, Margarida Maria Lacombe. Hermenêutica e argumentação: uma contribuição ao estudo do direito. 3. ed. Rio de Janeiro: Renovar, 2003. p. 133.
} 
interpretação constitucional. Neste sentido, a antiga controvérsia tem relação com o atual conceito de judicial review, considerado numa perspectiva mais ampla do que simples contexto restrito de revisão ou controle constitucional, ou seja, no sentido de sujeição da lei ao controle interpretativo do judiciário ${ }^{23}$. Portanto, a controvérsia se refere também à possibilidade de sujeição do significado da lei ao controle judicial, isto é, o exercício pelos tribunais da interpretação e atribuição de sentido à norma legal, em especial à Constituição.

No Brasil, à letra do que estabelece o texto constitucional ${ }^{24}$, ao Poder Judiciário é conferida a função de apreciar os fatos a ele submetidos e verificar a validade das leis e das decisões quanto a conformação à estrutura hierárquica normativa e ao significado constitucional possível. Por conseguinte, diferente dos Estados Unidos, por exemplo, o problema desse controle judicial interpretativo no sistema brasileiro não parece se assentar na dúvida acerca da permissão constitucional da função atribuída ao STF, pois esta é expressamente definida em lei. No Brasil, a questão não é nem um problema de legalidade, porque os juízes podem fazer o controle judicial, nem de legitimidade, porque a Constituição (a vontade do próprio povo, em princípio) reconhece esse poder exercido pelos tribunais como legítimo ${ }^{25}$. A questão reside mais na extensão e profundidade dessa revisão, o âmbito de sua legitimidade: $(i)$ o limite dos significados possíveis atribuídos ao texto da lei; e (ii) a amplitude ou não de análise dos fatos à conformação das leis pelas instâncias judiciais.

Quanto ao segundo aspecto, a análise dos fatos à conformação legal, a controvérsia incide sobre os limites da análise das provas nas instâncias judiciais superiores e, portanto, fora do âmbito temático deste artigo. Assim, ao que nos interessa, no que tange ao sentido atribuído pelo Tribunal ao texto legal, a questão relaciona-se aos limites da interpretação conferida pela Corte, até que ponto pode limitar, exceder ou destruir o sentido materialmente fixado pela própria Constituição. Controvérsia que, como veremos, atinge também o sentido das normas infraconstitucionais, na medida em que os valores ou conceitos essenciais da Constituição repercutem não só diretamente no significado atribuído a essas normas, mas também no conceito de democracia vigente.

$\mathrm{Na}$ verdade, as Cortes representam muito mais do que simples órgãos técnicos aplicadores da lei. Pelo contrário, suas intervenções afetam o processo político social. Apesar de

\footnotetext{
${ }^{23}$ Cf. WALDRON, Jeremy. The core of the case against judicial review. Yale Law Journal, v. 115, n. 6, p. 1346-1406, 2006. p. 1354.

${ }^{24}$ Como exemplo, o quanto disposto nos arts. $5^{\circ}, \mathrm{XXXV}, 102$ e 105, todos da CF/88.

25 Cf. AGUDELO, Carlos Agudelo. Una respuesta a la 'dificultad contramayoritaria' a partir de las 'virtudes pasivas' de los jueces. Precedente. Anuario Jurídico, California, v. 5, n. 03, p. 181-224, jul./dez. 2014. p. $192-193$.
} 
limitadas pela Constituição e pelo ordenamento, na prática, interpretações judiciais aplicadas aos casos podem levar o texto constitucional a sentidos dos mais diversos. Quer dizer, independentemente de ter ou não a última palavra, poder conferido sub silentio pela Constituição, a Suprema Corte tem o poder de levar a Constituição e as demais leis a determinado fim, cujo sentido, sem o resguardo de determinadas garantias, corre o risco de depender exclusivamente da própria vontade dos julgadores ${ }^{26}$.

\section{HC 126.292/SP: PRISÃO APÓS SEGUNDA INSTÂNCIA}

Sob a ótica do caso concreto, já em 2015, num artigo intitulado $A$ presunção de nãoculpabilidade, o Ministro Gilmar Mendes ${ }^{27}$ prenuncia a mudança no entendimento do Supremo Tribunal Federal (STF) acerca da legalidade do início de cumprimento da pena após a decisão em segunda instância. Já de antemão, questiona se o princípio constitucional da presunção de nãoculpabilidade, previsto no art. $5^{\circ}$, LVII, da CF/88, impede a prisão do condenado (provisório) após o julgamento pelo tribunal de apelação. E a partir dessa indagação, conclui que o entendimento do STF deveria ser revisto, tendo em conta dois fundamentos: (i) o princípio tem um âmbito de proteção sujeito à conformação pela legislação infraconstitucional; e (ii), mesmo que assim não se entenda, a prisão se justifica, em casos graves, pela garantia da ordem pública, uma vez esgotados os recursos ordinários.

Com relação à primeira razão apontada pelo Min. Gilmar Mendes, é certo que o direito de recorrer em liberdade, de acordo com a legislação ordinária (vide também a Súmula 9 do ST $\mathrm{J}^{28}$ ), dependerá de cada caso e, portanto, "deve-se analisar a situação à luz do sistema cautelar e da real necessidade que a fundamenta (periculum libertatis) e legitima [...]"29. De todo modo, restaria claramente distinto o âmbito da prisão cautelar e o da execução (provisória) da pena.

${ }^{26}$ ROCHE, John P. Judicial self-restraint. The American Political Science Review, v. 49, n. 3, p. 762-772, 1955. ISSN 0003-0554, 1537-5943. Disponível em: <http://www.jstor.org/stable/1951437>. Acesso em: 4 abr. 2018. p. 763.

27 MENDES, Gilmar Ferreira. A presunção de não culpabilidade e a orientação do ministro Marco Aurélio. Marco Aurélio Mello: ciência e consciência. Migalhas, v. 1, p. 33-48, 2015. Disponível em: < http:/ / www.migalhas.com.br/arquivos/2016/2/art20160217-09.pdf >. Acesso em 4 abr. 2018.

${ }^{28}$ BRASIL. Superior Tribunal de Justiça. Súmula $n^{\circ}$ 9. A exigência da prisão provisória, para apelar, não ofende a garantia constitucional da presunção de inocência. Brasília, DF, 1990. STJ, Terceira Seção, julgado em 06/09/1990, DJ 12/09/1990, p. 9278. Disponível em: < https://goo.gl/ywbbNK >. Acesso em: 4 abr. 2018.

${ }^{29}$ LOPES JR., Aury. Direito processual penal. 12. ed. São Paulo: Saraiva, 2015. p. 674. 
Os argumentos da segunda justificativa, por sua vez, formarão um dos motivos (re)apresentados pelo Ministro Barroso, no voto da Repercussão Geral - Tema $925^{30}$ para justificar a fundamentação (automática) da prisão, após o julgamento condenatório em segunda instância, tendo em vista a preservação da ordem pública e da credibilidade do Tribunal.

Assim, em 17 de fevereiro de 2016, no julgamento do HC 126.292, tendo como relator o Ministro Teori Zavascki, o STF entendeu, por maioria dos votos, que a execução da pena antes do trânsito em julgado da sentença não contraria a Constituição.

Em síntese, o paciente, condenado em primeira e segunda instâncias por crime de roubo majorado, impugnava a decisão do STJ que negou o pedido de Habeas Corpus, contra o acórdão do Tribunal do Estado de São Paulo que determinou o início do cumprimento da pena, após o julgamento da apelação. Muito embora a sentença condenatória em primeiro grau tivesse concedido ao réu o direito de recorrer em liberdade.

Ficou claro, desde o início, conforme o voto do relator ${ }^{31}$, que não se tratava de discussão em torno da possibilidade de prisão cautelar, mas sim da conformidade ou não do cumprimento (antecipado) da pena com o princípio constitucional do art. $5^{\circ}$, $\mathrm{LVII}$, da $\mathrm{CF} / 88$, ou seja, se o STF manteria ou não o posicionamento já firmado no HC $84.078^{32}$, no sentido de que a execução antecipada da pena é incompatível com o princípio da presunção de inocência.

Com voto favorável ao início da execução da pena, após a decisão em segunda instância, o Ministro relator tratou de esclarecer que não se tratava de uma decisão totalmente à deriva da jurisprudência do STF, uma vez que o próprio Tribunal já admitia a execução provisória antes do trânsito em julgado, cuja alteração só veio a ocorrer em 2009. Portanto, de acordo com o Min. relator Teori Zavascki, já na vigência da CF/88 e tendo como paradigma o HC 68.726 (Rel. Min. Néri da Silveira), de junho de 1991, o entendimento assente era no sentido de

${ }^{30}$ BRASIL. Supremo Tribunal Federal. Repercussão Geral. Tema 925. Plenário Virtual, Rel. Min. Teori Zavascki. Brasília, DF, julgado em 10/11/2016, DJe-251, 25 nov. 2016, ARE 964246 - RG. Disponível em: < https://goo.gl/tK6tcX >. Acesso em 30 mar. 2018.

${ }^{31}$ Cf. BRASIL. Supremo Tribunal Federal. Habeas Corpus $n^{\circ}$ 126.292/SP. Tribunal Pleno, Rel. Min. Teori Zavascki. Brasília, DF, julgado $17 \mathrm{fev}$. 2016, DJe-100, 17 mai. 2016. Disponível em: < http://portal.stf.jus.br/processos/downloadPeca.asp?id=311159272\&ext=.pdf >. Acesso em 30 mar. 2018. p. 4.

32 BRASIL. Supremo Tribunal Federal. Habeas Corpus $n^{\circ}$ 84.078/MG. Tribunal Pleno, Rel. Min. Eros Grau. Brasília, DF, DJe-035, julgado em 05 fev. 2009, publicado 26 fev. 2010, Ementário no 2391-5, p. 10481213. Disponível em: < http://redir.stf.jus.br/paginadorpub/paginador.jsp?docTP=AC\&docID=608531 > Acesso em 30 mar. 2018. 
que "a presunção de inocência não impede a prisão decorrente de acórdão que, em apelação, confirmou a sentença penal condenatória recorrível”33.

De acordo com o Min. Teori Zavascki, o voto pretendeu voltar à orientação parcialmente dominante que vigorava no Supremo, de modo a superar o marco estabelecido em 2009, no HC 84.078, e resgatando aquilo que, de 1995 a 2009, constituía pelo menos em parte o entendimento do $\mathrm{STF}^{34}$. Porém, deve-se ressaltar que essa interpretação da Suprema Corte, chamada de "tradicional” pelo Ministro relator ${ }^{35}$, favorável à execução antecipada da pena, não era pacífica, porque apesar de descrita no voto dos Ministros Teori Zavascki e Barroso como a orientação dominante até àquela data, constatamos pelo voto do Ministro Carlos Britto, no HC 84.078, de que a jurisprudência do STF não era uniforme, variando de acordo com o entendimento da Primeira ou da Segunda Turma:

Quando da análise da causa, no entanto, observei que a jurisprudência desta Suprema Corte de Justiça, em sua nova composição, não é uniforme sobre o tema. Há decisões proferidas por esta Colenda Primeira Turma no sentido de que a prisão do réu só é possível após o trânsito em julgado da condenação ou nas estritas hipóteses cautelares taxativamente previstas no art. 312 do Código de Processo Penal, assim como há julgados provenientes da Colenda Segunda Turma que entendem que os recursos especial e extraordinário nem por se privarem de efeito suspensivo, deixam de viabilizar a imediata prisão do condenado. Ou seja, as duas Turmas dissentem quanto à interpretação do art. 312 do CPP (grifouse) $)^{36}$.

O Ministro Gilmar Mendes, no seu voto em 2009, também deixa transparecer que a Primeira Turma do STF seguia a orientação de não permitir a antecipação do cumprimento da pena, sendo possível apenas a prisão, após a sentença condenatória, de natureza cautelar:

Pelo que eu depreendi, na Primeira Turma, a posição prevalente era sempre esta: a de que não se exclui a possibilidade da prisão com a sentença, ou mesmo

\footnotetext{
33 BRASIL. Supremo Tribunal Federal. Habeas Corpus $n^{\circ} 126.292 / S P$. Tribunal Pleno, Rel. Min. Teori Zavascki. Brasília, DF, julgado 17 fev. 2016, DJe-100, 17 mai. 2016. Disponível em: < http://portal.stf.jus.br/processos/downloadPeca.asp?id=311159272\&ext=.pdf >. Acesso em 30 mar. 2018. p. 5.

${ }^{34}$ BRASIL. Supremo Tribunal Federal. Habeas Corpus $n^{\circ}$ 126.292/SP. Tribunal Pleno, Rel. Min. Teori Zavascki. Brasília, DF, julgado 17 fev. 2016, DJe-100, 17 mai. 2016. Disponível em: < http://portal.stf.jus.br/processos/downloadPeca.asp?id=311159272\&ext=.pdf >. Acesso em 30 mar. 2018. p. 6 e $29-30$

${ }^{35}$ Vide a p. 7 do mesmo HC 126.292, por exemplo.

${ }^{36}$ BRASIL. Supremo Tribunal Federal. Habeas Corpus $n^{\circ}$ 84.078/MG. Tribunal Pleno, Rel. Min. Eros Grau. Brasília, DF, DJe-035, julgado em 05 fev. 2009, publicado 26 fev. 2010, Ementário no 2391-5, p. 10481213. Disponível em: < http://redir.stf.jus.br/paginadorpub/paginador.jsp?docTP=AC\&doclD=608531 >. Acesso em 30 mar. 2018. p. 1068-1069.
} 
com o acórdão na apelação, desde que presentes e identificados os fundamentos de prisão provisória, da prisão cautelar, os requisitos de cautelaridade ${ }^{37}$.

Consequentemente, sendo correta essa constatação, o HC 84.078 não provocou "a alteração dessa tradicional jurisprudência - que afirmava a legitimidade da execução da pena como efeito de decisão condenatória recorrível -" como ressaltou o Min. relator Teori Zavascki ${ }^{38}$, mas sim veio de fato para uniformizar o entendimento divergente entre a Primeira e a Segunda Turmas do STF, no julgamento paradigmático de 2009.

Deste modo, parece aceitável concluir que o voto do Ministro relator, no HC 126.292, procurava argumentos para reposicionar a orientação da Corte, em favor do anterior entendimento da Segunda Turma, ou seja, de que não há vedação constitucional ao início de cumprimento da pena antes do trânsito em julgado da sentença:

Realmente, a execução da pena na pendência de recursos de natureza extraordinária não compromete o núcleo essencial do pressuposto da nãoculpabilidade, na medida em que o acusado foi tratado como inocente no curso de todo o processo ordinário criminal, observados os direitos e as garantias a ele inerentes, bem como respeitadas as regras probatórias e o modelo acusatório atual. Não é incompatível com a garantia constitucional autorizar, a partir daí, ainda que cabíveis ou pendentes de julgamento de recursos extraordinários, a produção dos efeitos próprios da responsabilização criminal reconhecida pelas instâncias ordinárias ${ }^{39}$.

Assim, com a assertiva de reforço de que em nenhum outro país do mundo a prisão aguarda o referendum da Suprema Corte, o relator entende necessário o resgate do anterior entendimento, com vista a dar maior efetividade às sentenças, sem prejuízo de eventuais injustiças, uma vez que "o acusado não estará desamparado da tutela jurisdicional em casos de flagrante violação de direitos" ${ }^{40}$.

\footnotetext{
${ }^{37}$ BRASIL. Supremo Tribunal Federal. Habeas Corpus $n^{\circ}$ 84.078/MG. Tribunal Pleno, Rel. Min. Eros Grau. Brasília, DF, DJe-035, julgado em 05 fev. 2009, publicado 26 fev. 2010, Ementário no 2391-5, p. 10481213. Disponível em: < http://redir.stf.jus.br/paginadorpub/paginador.jsp?docTP=AC\&docID=608531 >. Acesso em 30 mar. 2018. p. 1124.

38 BRASIL. Supremo Tribunal Federal. Habeas Corpus $n^{\circ} 126.292 / S P$. Tribunal Pleno, Rel. Min. Teori Zavascki. Brasília, DF, julgado $17 \mathrm{fev}$. 2016, DJe-100, 17 mai. 2016. Disponível em: < http://portal.stf.jus.br/processos/downloadPeca.asp?id=311159272\&ext=.pdf >. Acesso em 30 mar. 2018. p. 7.

39 BRASIL. Supremo Tribunal Federal. Habeas Corpus $n^{\circ}$ 126.292/SP. Tribunal Pleno, Rel. Min. Teori Zavascki. Brasília, DF, julgado $17 \mathrm{fev}$. 2016, DJe-100, 17 mai. 2016. Disponível em: < http://portal.stf.jus.br/processos/downloadPeca.asp?id=311159272\&ext=.pdf >. Acesso em 30 mar. 2018. p. 12.

40 BRASIL. Supremo Tribunal Federal. Habeas Corpus $n^{\circ}$ 126.292/SP. Tribunal Pleno, Rel. Min. Teori Zavascki. Brasília, DF, julgado 17 fev. 2016, DJe-100, 17 mai. 2016. Disponível em: <
} 
Vencidos os Ministros Rosa Weber, Marco Aurélio, Celso de Mello e Ricardo Lewandowski, firma-se a orientação pela constitucionalidade do início do cumprimento provisório da pena, após a condenação proferida em apelação. Todavia, apesar do voto do Ministro relator esclarecer, por si só, os principais pontos que fundamentaram a nova orientação, é importante a análise de alguns aspectos tratados especificamente ou com mais pormenores em outros votos, de modo a transparecer as marcas desse (novo) entendimento.

\subsection{A literalidade do princípio: presunção de não-culpabilidade}

Neste sentido, o voto do Ministro Barroso traz vários elementos que ressaltam aspectos importantes da nova orientação, guardados em filigrana no voto do relator, d'une façon implicite, ou talvez tomando um sentido, dans une impression divergente, para além da vontade inicial de mudança, já que, em vários pontos, o fundamento do voto-relator resgata aspectos dos votos vencidos no HC 84.078, mas sem demonstrar a pretensão de superá-los.

Os argumentos do Min. Barroso, no sentido de que a execução da pena após a condenação em segundo grau não viola o princípio de inocência ou da não culpabilidade (art. $5^{\circ}$, LVII, da CF/88) se baseiam em "três fundamentos jurídicos" centrais. Primeiro, na literalidade do texto constitucional que, segundo ele, não condiciona a prisão, mas a culpabilidade. Neste sentido "o pressuposto para a privação de liberdade é a ordem escrita e fundamentada da autoridade judiciária competente, e não sua irrecorribilidade”, conforme a leitura sistemática dos incisos LVII e LXI do art. $5^{\circ}$ da Constituição ${ }^{41}$.

Em segundo lugar, a diferença conceitual entre princípios e regras, conforme a qual os primeiros permitem a ponderação, de acordo com outros princípios em jogo, como é, para a hipótese, o princípio da efetividade da lei penal (art. $5^{\circ}$, caput, LXXVIII e art. 144, todos da $\mathrm{CF} / 88$ ). Neste sentido, a presunção de inocência é princípio e não regra. Logo, o art. $283^{42}$ do CPP não pode servir como vedação interpretativa à execução da pena após a segunda instância,

http://portal.stf.jus.br/processos/downloadPeca.asp?id=311159272\&ext=.pdf >. Acesso em 30 mar. 2018. p. 19.

41 BRASIL. Supremo Tribunal Federal. Habeas Corpus $n^{\circ}$ 126.292/SP. Tribunal Pleno, Rel. Min. Teori Zavascki. Brasília, DF, julgado 17 fev. 2016, DJe-100, 17 mai. 2016. Disponível em: < http://portal.stf.jus.br/processos/downloadPeca.asp?id=311159272\&ext=.pdf >. Acesso em 30 mar. 2018. p. 27.

42 Art. 283 do CPP: Ninguém poderá ser preso senão em flagrante delito ou por ordem escrita e fundamentada da autoridade judiciária competente, em decorrência de sentença condenatória transitada em julgado ou, no curso da investigação ou do processo, em virtude de prisão temporária ou prisão preventiva (conforme a redação que lhe conferiu a Lei $n^{\circ} 12.403$, de 2011, grifou-se). 
uma vez que se trata de norma infraconstitucional ${ }^{43}$. Por fim, como terceiro fundamento, 0 resgate da credibilidade do Poder Judiciário e do sistema penal, devido à efetividade da condenação, entenda-se, o início da execução da pena.

A par desses "fundamentos jurídicos", o Min. Barroso elenca ainda mais "três fundamentos pragmáticos” em favor do início do cumprimento da pena antes do trânsito em julgado: (i) torna mais funcional e equilibrado o sistema criminal porque inibe a interposição sucessiva de recursos protelatórios; (ii) torna mais republicano e igualitário o sistema, em vista da maior eficácia do cumprimento da pena, principalmente no que tange à chamada "criminalidade de colarinho branco"; e (iii) "promove a quebra do paradigma da impunidade do sistema penal" ${ }^{44}$.

Ainda segundo o Min. Barroso, a mudança de entendimento do STF provocou três efeitos negativos: a) "poderoso incentivo" à interposição de recursos protelatórios; $b$ ) reforço da seletividade do sistema criminal que, segundo o mesmo, favorece os "réus abastados" que podem interpor sucessivos recursos: "não por acaso, [...] mais fácil prender um jovem de periferia [...] do que um agente político ou empresário [...]"; c) o descrédito da justiça, uma vez que o aguardar do julgamento dos Recursos Especiais (REsp) e Recursos Extraordinários (RE) leva "massivamente à prescrição da pretensão punitiva" 45 .

Assim, vota também pela denegação da ordem, com tese similar ao do relator, mas com a relevante diferença de ressaltar expressamente a nomenclatura do princípio, ou seja, trata-se de princípio de não-culpabilidade, em vez de princípio da presunção de inocência. Quer dizer, de antemão, o Ministro Barroso já explicita a sua compreensão do que seria tecnicamente o mais correto: "o dispositivo consagra o princípio da presunção de inocência, ou - no termo mais técnico - o princípio da presunção de não-culpabilidade" (grifou-se) ${ }^{46}$.

${ }^{43}$ Cf. BRASIL. Supremo Tribunal Federal. Habeas Corpus $n^{\circ} 126.292 / S P$. Tribunal Pleno, Rel. Min. Teori Zavascki. Brasília, DF, julgado 17 fev. 2016, DJe-100, 17 mai. 2016. Disponível em: < http://portal.stf.jus.br/processos/downloadPeca. asp?id=311159272\&ext=.pdf >. Acesso em 30 mar. 2018. p. 39.

44 BRASIL. Supremo Tribunal Federal. Habeas Corpus $n^{\circ}$ 126.292/SP. Tribunal Pleno, Rel. Min. Teori Zavascki. Brasília, DF, julgado 17 fev. 2016, DJe-100, 17 mai. 2016. Disponível em: < http://portal.stf.jus.br/processos/downloadPeca.asp?id=311159272\&ext=.pdf >. Acesso em 30 mar. 2018. p. 28.

45 BRASIL. Supremo Tribunal Federal. Habeas Corpus $n^{\circ} 126.292 / S P$. Tribunal Pleno, Rel. Min. Teori Zavascki. Brasília, DF, julgado 17 fev. 2016, DJe-100, 17 mai. 2016. Disponível em: < http://portal.stf.jus.br/processos/downloadPeca.asp?id=311159272\&text=.pdf >. Acesso em 30 mar. 2018. p. 32-34.

46 BRASIL. Supremo Tribunal Federal. Habeas Corpus $n^{\circ}$ 126.292/SP. Tribunal Pleno, Rel. Min. Teori Zavascki. Brasília, DF, julgado 17 fev. 2016, DJe-100, 17 mai. 2016. Disponível em: < http://portal.stf.jus.br/processos/downloadPeca.asp?id=311159272\&ext=.pdf >. Acesso em 30 mar. 2018. p. 26. 
Neste aspecto, o Min. Barroso ressalta a "tecnicidade" da expressão constitucional, tendo como critério a sua própria literalidade, dado que não há utilização expressa de irrecorribilidade, mas sim de culpabilidade. E conforme o seu raciocínio, o fundamento constitucional da prisão não é o esgotamento das vias recursais nas instâncias superiores, mas a ordem escrita e fundamentada do juiz ${ }^{47}$. Para tanto, o voto confronta os incisos LVII e LXI, ambos do art. $5^{\circ}$ da $\mathrm{CF} / 88$, no que os vocábulos têm de sintagmático, isto é, o "considerado culpado" e o "será preso". Para concluir que, "assim, considerando-se ambos os incisos, é evidente que a Constituição diferencia o regime da culpabilidade e o da prisão" ${ }^{48}$.

Portanto, ao menos prima facie, há uma tentativa de se buscar o sentido pretendido pela própria Constituição. 0 problema é que o argumento utiliza a mesma justificativa para fundamentar interpretações opostas. Em primeiro lugar, a literalidade da Constituição é utilizada para justificar (e combater) a decisão contrária à execução da pena antes do trânsito em julgado, no HC 84.078, que por maioria dos votos interpretou o princípio da presunção de não-culpabilidade, "em favor de uma leitura mais literal" 49 . Quer dizer, de acordo com o voto do Min. Barroso, interpretou-se o princípio do art. $5^{\circ}$, LVII, como impeditivo ao cumprimento antecipado da pena porque houve uma leitura muito literal da Constituição, naquele Habeas Corpus de 2009. O que para ele, nos parece, não devia ser o caso.

Por outro lado, o próprio Ministro se utiliza do argumento da literalidade para, primeiro, defender que não se trata “tecnicamente" de um princípio da inocência, e sim de princípio constitucional de não-culpabilidade, conforme a letra da Lei, que não fala em “inocência”, mas em "não culpado". Segundo, faz uso novamente da literalidade dos dispositivos constitucionais para, agora, ao confrontar "culpabilidade" e "prisão", subtender que a segunda não implica a primeira. Consequentemente, o voto assume, quando lhe é favorável, a mesma estratégia literal do texto que pretende combater, sem, entretanto, fazer a ressalva de um ad argumentandum tantum.

47 BRASIL. Supremo Tribunal Federal. Habeas Corpus $n^{\circ}$ 126.292/SP. Tribunal Pleno, Rel. Min. Teori Zavascki. Brasília, DF, julgado 17 fev. 2016, DJe-100, 17 mai. 2016. Disponível em: < http://portal.stf.jus.br/processos/downloadPeca.asp?id=311159272\&ext=.pdf >. Acesso em 30 mar. 2018. p. 35-36.

48 BRASIL. Supremo Tribunal Federal. Habeas Corpus $n^{\circ} 126.292 / S P$. Tribunal Pleno, Rel. Min. Teori Zavascki. Brasília, DF, julgado 17 fev. 2016, DJe-100, 17 mai. 2016. Disponível em: < http://portal.stf.jus.br/processos/downloadPeca.asp?id=311159272\&ext=.pdf >. Acesso em 30 mar. 2018. p. 36.

${ }^{49}$ Cf. BRASIL. Supremo Tribunal Federal. Habeas Corpus $n^{\circ}$ 126.292/SP. Tribunal Pleno, Rel. Min. Teori Zavascki. Brasília, DF, julgado $17 \mathrm{fev}$. 2016, DJe-100, 17 mai. 2016. Disponível em: < http://portal.stf.jus.br/processos/downloadPeca.asp?id=311159272\&ext=.pdf >. Acesso em 30 mar. 2018. p. 30. 


\subsection{0 ativismo da esperança antecipada da pena}

Já estava presente no voto do Ministro-relator a preocupação com a efetividade das sentenças penais, uma das causas apontadas como fator de diminuição da credibilidade do Poder Judiciário, cuja necessidade o Min. Barroso sustentará como um dos "fundamentos pragmáticos", para justificar o cumprimento da pena antes do trânsito em julgado:

Impedir que condenações proferidas em grau de apelação produzam qualquer consequência, conferindo aos recursos aos tribunais superiores efeito suspensivo que eles não têm por força de lei, fomenta a utilização abusiva e protelatória da quase ilimitada gama de recursos existente em nosso sistema penal ${ }^{50}$.

Assim, o "pragmatismo" se junta às condições de validade da norma para determinar se uma decisão é (in)constitucional. C'est à dire, a constitucionalidade passa não só a depender da relação de conformidade da decisão ou da norma infraconstitucional ao texto da Constituição, mas também, ao menos como justificativa complementar, do ajuste pragmático que decorre do resultado decisório.

Como se extrai de parte do voto do Min. Barroso, afirmar que a execução da pena antes do trânsito em julgado é inconstitucional (e insuportável) não faz sentido, não pela própria natureza do ato e seus efeitos, mas porque esvazia de sentido o fato de que há presos preventivos que "superlotam as prisões brasileiras", cujo cárcere, segundo o próprio Ministro, pode perdurar por anos sem uma única decisão condenatória sequer ${ }^{51}$.

Por conseguinte, face à intolerável condição de inúmeros acusados presos, sequer julgados, que "superlotam as prisões brasileiras", cria-se uma suposta regra de equidade em que, embora à desconfiança da lei, não sendo possível contemplar a todos, a ninguém é devida a justiça da norma. Consequentemente, esvazia-se a regra de tratamento ${ }^{52}$ decorrente do

50 BRASIL. Supremo Tribunal Federal. Habeas Corpus $n^{\circ}$ 126.292/SP. Tribunal Pleno, Rel. Min. Teori Zavascki. Brasília, DF, julgado 17 fev. 2016, DJe-100, 17 mai. 2016. Disponível em: < http://portal.stf.jus.br/processos/downloadPeca. asp?id=311159272\&ext=.pdf >. Acesso em 30 mar. 2018. p. 51.

${ }^{51}$ Cf. BRASIL. Supremo Tribunal Federal. Habeas Corpus $n^{\circ}$ 126.292/SP. Tribunal Pleno, Rel. Min. Teori Zavascki. Brasília, DF, julgado 17 fev. 2016, DJe-100, 17 mai. 2016. Disponível em: < http://portal.stf.jus.br/processos/downloadPeca.asp?id=311159272\&ext=.pdf >. Acesso em 30 mar. 2018. p. 52.

52 Sobre as duas regras de tratamento decorrente do princípio da presunção de inocência, vide, por exemplo, o voto do Ministro. Celso de Mello. BRASIL. Supremo Tribunal Federal. Habeas Corpus $\mathrm{n}^{\circ}$ 126.292/SP. Tribunal Pleno, Rel. Min. Teori Zavascki. Brasília, DF, julgado 17 fev. 2016, DJe-100, 17 mai. 
princípio da presunção de inocência ou - "tecnicamente" - do princípio de não-culpabilidade, como pretende o citado voto, para "reduzir o grau de seletividade do sistema punitivo brasileiro", denominado de "efeito republicano e igualitário", provocando, segundo o mesmo voto, um "impacto positivo sobre o número de pessoas presas temporariamente", posto que servirá para esfriar "a tentação de juízes e tribunais de prenderem ainda durante a instrução"53.

De certo modo, a esperança, de que juízes prenderão menos, torna-se o fundamento pragmático da decisão, que além de qualquer (outra) possibilidade de controle, apenas a esperança, almeja trazer justiça ao estado de coisas inconstitucional do sistema carcerário brasileiro (vide ADPF 327), sob o argumento daquilo que optou chamar de "efeito republicano e igualitário".

Porém, sob a ótica do resultado pretendido, a perspectiva é de uma solução às avessas, ou seja, tendo reconhecido a ilegalidade e estrutural violação da dignidade humana do sistema carcerário brasileiro, a importação do modelo latino-americano, decorrente da Sentencia T-025, de 2004, da Corte Constitucional colombiana (CCC), nem mesmo chegou perto da efetividade desta, na comparação direta entre moradia vs. superencarceramento. Definitivamente, um estado de coisas fora do lugar, como definiram José Ribas Vieira e Rafael Bezerra ${ }^{54}$. Uma versão brasileira do "ativismo dialógico" que concretiza os efeitos denunciados por Lenio Streck quanto a uma declaração tão abrangente de inconstitucionalidade pelo STF e que já antecipava os perigos dessa retórica paradoxal ${ }^{55}$.

Numa espécie de alienista machadian ${ }^{56}$, tendo em vista a quantidade de presos provisórios e na esperança de que venha a frear "a tentação de juízes e tribunais de prenderem", o voto preconiza antecipar também a prisão daqueles, alguns, que ainda sobejarem soltos após a sentença. Tal "eficácia prisional”, apregoada pelo Min. Zavascki e fundamentada

2016. Disponível em: < http://portal.stf.jus.br/processos/downloadPeca.asp?id=311159272\&ext=.pdf >. Acesso em 30 mar. 2018. p. 84 e segs.

53 BRASIL. Supremo Tribunal Federal. Habeas Corpus $n^{\circ} 126.292 / S P$. Tribunal Pleno, Rel. Min. Teori Zavascki. Brasília, DF, julgado 17 fev. 2016, DJe-100, 17 mai. 2016. Disponível em: < http://portal.stf.jus.br/processos/downloadPeca.asp?id=311159272\&ext=.pdf >. Acesso em 30 mar. 2018. p. 52.

${ }^{54}$ VIEIRA, José Ribas; BEZERRA, Rafael. Estado de coisas fora do lugar (?). Jota, 5 out. 2015. Disponível em: < https://www.jota.info/opiniao-e-analise/artigos/estado-de-coisas-fora-lugar-05102015\#_ftn6 >. Acesso em: 10 out. 2015.

55 STRECK, Lenio. Estado de coisas inconstitucional é uma nova forma de ativismo. Conjur, 24 out. 2015. Observatório Constitucional. Disponível em: <https://goo.gl/9QwuNh>. Acesso em: 30 mar. 2018.

56 STRECK,Concretiza-se, à semelhança da profecia literária, a terceira conclusão do alienista oficiada à Câmara, de "que se devia admitir como normal e exemplar o desequilíbrio das faculdades e como hipóteses patológicas todos os casos em que aquele equilíbrio fosse ininterrupto". ASSIS, Machado de. 0 alienista. In: Obra Completa de Machado de Assis. Vol. I. Rio de Janeiro: Nova Aguilar, 1994. Cap. XI: O Assombro de Itaguaí. 
pelo Min. Barroso, fora antecipadamente revelada por De Giorgi e Campilongo, numa análise que talvez só agora faz todo o sentido de sua alerta: “Se assim estão as 'coisas' - e, por isso, a ordem jurídica é ineficaz e o acesso à Justiça não se concretiza -, por que não decretar a inconstitucionalidade da Constituição e determinar o fechamento dos tribunais?" ${ }^{57}$.

Um problema cujos efeitos, posteriormente, no julgamento da Medida Cautelar na ADC 44, o Min. Celso de Mello enfatizou a natureza alarmante, numa de suas indagações: “Até quando dados meramente estatísticos poderão autorizar essa inaceitável hermenêutica de submissão, de cuja utilização resulte, como efeito perverso, gravíssima e frontal transgressão ao direito fundamental de ser presumido inocente?"58.

Sem contar que permanece ainda pendente uma definição do regime prisional a que tais condenados (provisórios) vêm sendo submetidos, com a prisão antes do trânsito em julgado e face à situação carcerária brasileira. Esta preocupação é relevante e foi suscitado pelo Ministro Dias Toffoli, quanto ao cumprimento da Lei de Execução Penal (arts. $2^{\circ}$ e 84 da Lei 7.210/84), no que tange ao tratamento diferenciado do preso provisório e do condenado com sentença transitada em julgado, cuja custódia deve ocorrer separadamente ${ }^{59}$.

Mas do que se pode "suspeitar" da amplitude do voto do Ministro Barroso, cuja fundamentação parece orientar neste momento a eficácia da nova orientação, a Constituição não só não é adversa à prisão antes do trânsito em julgado, como o próprio início definitivo da execução da pena estaria legitimamente assegurado (ou não proibido) pelo texto constitucional. Neste aspecto, se o voto do Ministro-relator foi sempre pautado pelo caráter provisório da execução antes do trânsito em julgado, os argumentos do voto do Min. Barroso tendem a ignorar a natureza antecipada e provisória da pena após a decisão em segundo grau, modificando o termo a quo do cumprimento da pena ${ }^{60}$.

57 DE GIORGI, Raffaele; FARIA, José Eduardo; CAMPILONGO, Celso. Estado de coisas inconstitucional. Estadão, São Paulo, 19 set. 2015. Opinião. Disponível em: < http://opiniao.estadao.com.br/noticias/geral,estado-de-coisas-inconstitucional,10000000043 >. Acesso em: 21 set. 2015.

58 BRASIL. Supremo Tribunal Federal. Medida Cautelar na Ação Declaratória de Constitucionalidade 44 DF. Tribunal Pleno, Rel. Min. Marco Aurélio. Brasília, DF, ATA 23/2018, divulgado 6 mar. 2018, DJe 43, publicado 7 mar. 2018, ADC 44 - MC. Inteiro Teor do Acórdão (Medida Cautelar). Disponível em: < http://www.stf.jus.br/portal/processo/verProcessoPeca.asp?id=313832408\&tipoApp=.pdf >. Acesso em: 30 mar. 2018. p. 219 (do Inteiro Teor).

59 BRASIL. Supremo Tribunal Federal. Medida Cautelar na Ação Declaratória de Constitucionalidade 44 DF. Tribunal Pleno, Rel. Min. Marco Aurélio. Brasília, DF, ATA 23/2018, divulgado 6 mar. 2018, DJe 43, publicado 7 mar. 2018, ADC 44 - MC. Inteiro Teor do Acórdão (Medida Cautelar). Disponível em: < http://www.stf.jus.br/portal/processo/verProcessoPeca.asp?id=313832408\&tipoApp=.pdf >. Acesso em: 30 mar. 2018. p. 168.

${ }^{60}$ Cf. BRASIL. Supremo Tribunal Federal. Medida Cautelar na Ação Declaratória de Constitucionalidade 44 DF. Tribunal Pleno, Rel. Min. Marco Aurélio. Brasília, DF, ATA 23/2018, divulgado 6 mar. 2018, DJe 43, 


\section{A PRAGMÁTICA DO TEXTO NO HC 126.292 E SUA LIMITAÇÃO}

Situamo-nos face a uma pragmática do texto em que, se correta a leitura de Perelman ${ }^{61}$, não é possível controlar o valor que serve de fundamentação, posto que não é possível sujeitá-lo a nenhum controle racional e qualquer valor pode, em tese, servir de fundamento ${ }^{62}$. Nesta perspectiva, o leitor do texto pode conferir-lhe, em princípio, à mercê das circunstâncias, fundamentos diversos, conforme lhe sirvam ao fim a que se propõe.

Uma atividade interpretativa que, para além do sentido literal que talvez todo texto apresenta, propõe-se a extrair-lhe significados outros, presentes apenas nas entrelinhas, não explícitas, mas pressupostas. 0 que, de acordo com Eco, definimos como uma pragmática do texto:

A atividade cooperativa que leva o destinatário a tirar do texto aquilo que o texto não diz (mas que pressupõe, promete, implica e implicita), a preencher espaços vazios, a conectar o que existe naquele texto com a trama da intertextualidade da qual aquele texto se origina e para a qual acabará confluindo ${ }^{63}$.

Uma pragmática que, por assim dizer, leva em conta os efeitos que os signos textuais provocam nos seus leitores-destinatários, em especial, na conduta que adotam perante a interpretação desses $\operatorname{signos}^{64}$. Todavia, tal atividade não se resume a um nominalismo extremo em que, na expressão de Valéry, Il n'y a pas de vrai sens d'un texte ${ }^{65}$ (não há sentido verdadeiro de um texto). Pelo contrário, entendemos que a interpretação jurídica deve se sustentar na

publicado 7 mar. 2018, ADC 44 - MC. Inteiro Teor do Acórdão (Medida Cautelar). Disponível em: < http://www.stf.jus.br/portal/processo/verProcessoPeca. asp?id=313832408\&tipoApp=.pdf >. Acesso em: 30 mar. 2018. p. 99 e segs.

${ }^{61}$ Cf. PERELMAN, Chaïm. Ética e direito. Trad. de Ermantina Galvão G. Pereira. São Paulo: Martins Fontes, 1996. p. 68 e segs.

${ }^{62}$ Cf. CAMARGO, Margarida Maria Lacombe. Hermenêutica e argumentação: uma contribuição ao estudo do direito. 3. ed. Rio de Janeiro: Renovar, 2003. p. 196.

63 ECO, Umberto. Lector in fabula: a cooperação interpretativa nos textos narrativos. São Paulo: Perspectiva, 2011. p. IX.

64 ECO, Umberto. Lector in fabula: a cooperação interpretativa nos textos narrativos. São Paulo: Perspectiva, 2011. p. 28.

${ }^{65}$ Interessante notar que a frase de Paul Valéry, no seu ensaio sobre poética, Au sujet du "Cémitière Marin', em que discute seu próprio poema, Cémitière Marin, numa espécie de "niilismo hermenêutico", como observa Pimentel, refere-se muito mais à interpretação de poesia (na perspectiva da poesia pura) do que a de prosa. PIMENTEL, Brutus Abel Fratuce. Paul Valéry: estudos filosóficos. 2008. $187 \mathrm{f}$. Tese (Doutorado em Filosofia) - Faculdade de Filosofia, Letras e Ciências Humanas, Universidade de São Paulo, São Paulo. Disponível em: < https://goo.gl/K321Ad >. Acesso em: 7 abr. 2018. nota 148, f. 52. 
aplicação de um dado sentido normativo que toma como base a forma dialógica, cuja sustentação exige, no mínimo, a presença de um interlocutor, cuja figura abstrata, seguindo a expressão modelada por Perelman, representa um "auditório", capaz de justificar a racionalidade da interpretação ${ }^{66}$.

Assim, muito diferente de uma prática solipsista, o conceito implica um sentido ampliado. Uma pragmática do texto (jurídico) que depende, além da natureza do autor (quem escreve), do leitor (quem lê), do contexto da mensagem (dito de outra forma, do conjunto da obra em que está inserida) e das circunstâncias externas (do auditório ${ }^{67}$, ou seja, de quem escuta, a quem é endereçada a leitura, do caso a que se aplica, da expectativa social e das consequências, por assim dizer) em que a mensagem é produzida, a partir de um background knowledge ou, na terminologia de Eco, a partir da enciclopédia:

Isto é, faz parte da pragmática a suposição, da parte de quem fala, que quem ouve já saiba muitas outras coisas, ditas antes de essa expressão-mensagem ser emitida. E diz respeito à pragmática o fato de estarem - quem ouve, ou quem fala - dispostos a aceitar, ou a não aceitar, este conhecimento de fundo ${ }^{68}$.

Deste modo, uma prática de leitura que interpreta ou mesmo faz uso do texto para retirar-lhe consequências, pode ser classificada nesta pragmática pela expressão "feliz" ou "infeliz", conforme suas conclusões cumpram ou não uma "regra de felicidade" da expressão ${ }^{69}$. Quer dizer, a pragmática se justifica porque o texto é um mecanismo preguiçoso ou econômico que se sustenta à base da valorização de sentido que o leitor-destinatário ali introduz, pois está cheio de espaços e interstícios que devem ser preenchidos e exige, na sua preguiça, "que alguém o ajude a funcionar"70.

Trata-se de um mecanismo simbólico, composto por uma série de artifícios de expressão, em que o sentido é sempre incompleto e requer, por duas razões, a sua atualização

\footnotetext{
${ }^{66}$ Cf. CAMARGO, Margarida Maria Lacombe. Hermenêutica e argumentação: uma contribuição ao estudo do direito. 3. ed. Rio de Janeiro: Renovar, 2003. p. 199-202.

${ }^{67}$ Neste sentido, é interessante ressaltar que o auditório, ainda que uma construção imaginária do orador, sob as condições de uma argumentação racional, exerce uma permanente influência sobre o orador que, não poucas vezes, vê-se obrigado a ajustar o seu discurso. CAMARGO, Margarida Maria Lacombe. Hermenêutica e argumentação: uma contribuição ao estudo do direito. 3. ed. Rio de Janeiro: Renovar, 2003. p. 212.

${ }^{68}$ ECO, Umberto. Conceito de texto. trad. Carla de Queiroz. São Paulo: Universidade de São Paulo, 1984. p. 16.

${ }^{69}$ ECO, Umberto. Conceito de texto. trad. Carla de Queiroz. São Paulo: Universidade de São Paulo, 1984. p. 17.

70 ECO, Umberto. Lector in fabula: a cooperação interpretativa nos textos narrativos. São Paulo: Perspectiva, 2011. p. 37.
} 
pelo leitor. Em primeiro lugar, o texto, como mensagem, "permanece puro lemph\{flatus vocis\} enquanto não for correlacionada, com referência a um determinado código, ao seu conteúdo convencionado", em que o leitor é sempre chamado a atuar (não necessariamente de forma empírica) para poder reconhecer os termos no contexto da frase ${ }^{71}$. Em segundo lugar, enquanto uma complexidade entremeada pelo não-dito, sempre postula a cooperação do leitor "como condição indispensável" da "potencialidade significativa"72.

Todavia, embora o texto esteja em princípio aberto a qualquer dos seus possíveis significados, em que, à moda de Paul Valéry, Il n'y a pas de vrai sens d'un texte, uma pragmática (jurídica) do texto não permite uma corrente infinita de interpretações, ao gosto do intérprete. Trata-se de um diferença significativa entre "interpretar um texto" e "usar (ao bel-prazer) um texto". O universo do discurso intervém para delimitar a interpretação do seu texto, ou seja, “intervém então para limitar o formato da enciclopédia”, representando o texto uma estratégia constituída pelo seu universo discursivo legitimável ${ }^{73}$.

No universo de interpretações (possíveis), caracterizado por essa "riqueza de implicitações, promessas argumentativas, pressuposições remotas", a interpretação deve atuar para delimitar os rumos interpretativos e, por conseguinte, a projeção de universos do discurso ${ }^{74}$, conforme a pertinência que considera as condições da enunciação, o contexto da mensagem e da anunciação, as circunstâncias externas e a enciclopédia de base em que o texto foi/é produzido. De modo que não venha a ocorrer, ao extremo uso do texto, no âmbito constitucional, por exemplo, a declaração de inconstitucionalidade da própria Constituição, como tragicamente advertiram De Giorgi e Campilongo ${ }^{75}$.

Quanto ao sentido do texto constitucional, o art. $5^{\circ}$, LVII, da $\mathrm{CF} / 88$, ninguém será considerado culpado até o trânsito em julgado de sentença penal condenatória, é preciso, em primeiro lugar, ter-se em conta que se trata de um texto público, em que as condições de anunciação não dependem exclusivamente nem da vontade do seu autor-legislador, nem da

71 ECO, Umberto. Lector in fabula: a cooperação interpretativa nos textos narrativos. São Paulo: Perspectiva, 2011. p. 35.

72 Cf. ECO, Umberto. Lector in fabula: a cooperação interpretativa nos textos narrativos. São Paulo: Perspectiva, 2011. p. 36-37.

73 “E um texto outra coisa não é senão a estratégia que constitui o universo das duas interpretações legitimáveis - se não “legítimas'”. ECO, Umberto. Lector in fabula: a cooperação interpretativa nos textos narrativos. São Paulo: Perspectiva, 2011. p. 44.

74 ECO, Umberto. Lector in fabula: a cooperação interpretativa nos textos narrativos. São Paulo: Perspectiva, 2011. p. 31.

${ }^{75} \mathrm{Cf}$. DE GIORGI, Raffaele; FARIA, José Eduardo; CAMPILONGO, Celso. Estado de coisas inconstitucional. Estadão, São Paulo, 19 set. 2015. Opinião. Disponível em: < http://opiniao.estadao.com.br/noticias/geral,estado-de-coisas-inconstitucional,10000000043 >. Acesso em: 21 set. 2015. 
vontade do leitor-intérprete. Trata-se de um texto, cujo percurso interpretativo se reporta à sua significação ideológica ou valorativa já definida por uma comunidade jurídica ou mesmo àquilo que Eco denominou de "fantasma do Leitor-Modelo":

Se aquele texto executa um trajeto comunicativo mais amplo e circula como texto "público" não mais atribuível ao seu sujeito enunciativo original, então será preciso vê-lo na sua nova situação comunicativa, como texto que, por intermédio do fantasma de um Autor-Modelo muito genérico, se reporta ao sistema de código e subcódigos aceito pelos seus possíveis destinatários e que, por conseguinte, quer ser atualizado segundo a competência de destinação. 0 texto conotará então discriminação ideológica ${ }^{76}$.

Quer dizer, a Constituição, por exemplo, assente como um texto público ${ }^{77}$, não depende mais da exclusiva vontade do(s) seu(s) autor(es) empírico(s), porque em razão de circunstâncias e eventos que decorrem da própria trajetória do texto (interpretativo), a enciclopédia que traduz o significado textual não coincide mais com a vontade (de significação) do autor empírico. Um sentido que, conforme as circunstâncias do tempo e modo de anunciação, pode ser legitimamente atualizável, sob pena de se tornar uma leitura isolada, alienígena à comunidade $^{78}$. Nesta ótica, a conclusão decisiva do HC 126.292 é legitimamente possível, posto que não obrigada a coincidir com o sentido pretendido pelo autor (original) do texto, na hipótese, o suposto poder constituinte.

Porém, um texto especial, como o é a Constituição, cuja autoridade e vontade última se referem à própria comunidade política à qual se aplica, já carrega "as intenções [de sua interpretação] virtualmente contidas no enunciado"79. E isto é relevante porque o intérprete, na hipótese, o STF, enquanto "sujeito de uma estratégia textual", não depende (sua leitura) da vontade ou intenção original do autor-empírico. Mas não pode, por outro lado, por ser a Constituição, o texto que ela mesma representa, deixar de reconhecer e afirmar "o peso que adquirem as circunstâncias de enunciação" ${ }^{80}$. Neste caso, o que a Constituição diz, nas condições da anunciação, não pode destoar demasiadamente do que a Constituição quis dizer,

76 ECO, Umberto. Lector in fabula: a cooperação interpretativa nos textos narrativos. São Paulo: Perspectiva, 2011. p. 47.

${ }^{77}$ Aqui nem se cogita da conclusão contrária, dada a natureza pública da Constituição.

${ }^{78} \mathrm{Cf}$. ECO, Umberto. Lector in fabula: a cooperação interpretativa nos textos narrativos. São Paulo: Perspectiva, 2011. p. 47.

79 Cf. ECO, Umberto. Lector in fabula: a cooperação interpretativa nos textos narrativos. São Paulo: Perspectiva, 2011. p. 46.

80 ECO, Umberto. Lector in fabula: a cooperação interpretativa nos textos narrativos. São Paulo: Perspectiva, 2011. p. 48. 
nas suas circunstâncias de enunciação ${ }^{81}$. Portanto, uma pragmática do texto que, por sua própria natureza constitutiva, tem como relevante a vontade do seu autor-modelo (mas empiricamente identificável no poder constituinte derivado) não pode ignorar por completo o que, histórica e sociologicamente considerados, pretendeu o texto.

$\mathrm{Na}$ interpretação do art. $5^{\circ}$, LVII, da CF/88, não está em dúvida tratar-se ou não de um princípio constitucional basilar, cujos efeitos práticos devem se estender por todo o processo criminal. A questão incide particularmente sobre os efeitos que essa não-culpabilidade pode obrigatoriamente gerar. A controvérsia interpretativa, quanto ao deslocamento de significado do princípio, tem a ver com os efeitos práticos que decorrem da conclusão, ou seja, a sua funcionalidade. A leitura que se extrai do texto constitucional, qualquer que seja ela, não pode ignorar o fato da enciclopédia e grande parte da comunidade jurídica (de leitores) considerar a prisão processual, antes do trânsito em julgado, como medida excepcional ${ }^{82}$.

Ainda que se considere, por exemplo, os precedentes originários da Súmula 9 do STJ ${ }^{83}$, a enciclopédia ${ }^{84}$ de que se faz uso no respectivo enunciado não ameaça o sentido da tradicional diferença entre execução da pena e prisão cautelar. Por outro lado, não se pode ignorar que, mesmo após a vigência do entendimento firmado no HC 84.078 pelo STF, firmou-se e permanece em vigor (i.e. não cancelada) a interpretação da Súmula 267 do STJ ${ }^{85}$, cujo enunciado e

81 Há ênfase numa peculiar diferença que se quer evidenciar, entre a circunstância de anunciação, ou seja, o que o texto, pela sua leitura, dá a conhecer, faz saber, noticia textualmente, e as circunstâncias de enunciação, o que pretendeu, enquanto processo comunicativo, afirmar, manifestar, enunciar.

82 Cf. GIAGOMOLLI, Nereu José. O devido processo penal: abordagem conforme a Constituição Federal e o Pacto de São José da Costa Rica. São Paulo: Atlas, 2014. p. 87-111.

${ }^{83}$ BRASIL. Superior Tribunal de Justiça. Súmula $n^{\circ}$ 9. A exigência da prisão provisória, para apelar, não ofende a garantia constitucional da presunção de inocência. Brasília, DF, 1990. STJ, Terceira Seção, julgado em 06/09/1990, DJ 12/09/1990, p. 9278. Disponível em: < https://goo.gl/ywbbNK >. Acesso em: 4 abr. 2018.

${ }^{84} \mathrm{E}$ se a cultura jurídica internacional pode servir de fundamento interpretativo, para a confirmação da enciclopédia em uso, é interessante notar que praticamente toda a comunidade jurídica de língua portuguesa adota o princípio da presunção de inocência e seus efeitos do antes/após o trânsito em julgado, no que tange ao status libertatis do condenado. Cf. BRASIL. Supremo Tribunal Federal. Habeas Corpus $n^{\circ}$ 126.292/SP. Tribunal Pleno, Rel. Min. Teori Zavascki. Brasília, DF, julgado 17 fev. 2016, DJe100, 17 mai. 2016.2 Disponível em: http://portal.stf.jus.br/processos/downloadPeca.asp?id=311159272\&ext=.pdf >. Acesso em 30 mar. 2018. p. 71. No mesmo sentido, MENDES, Gilmar Ferreira. A presunção de não culpabilidade e a orientação do ministro Marco Aurélio. Marco Aurélio Mello: ciência e consciência. Migalhas, v. 1, p. 33-48, 2015. Disponível em: < http://www.migalhas.com.br/arquivos/2016/2/art20160217-09.pdf >. Acesso em 4 abr. 2018.

${ }^{85}$ BRASIL. Superior Tribunal de Justiça. Súmula $n^{\circ}$ 267. A interposição de recurso, sem efeito suspensivo, contra decisão condenatória não obsta a expedição de mandado de prisão. [S.l.], 2002. STJ, Terceira Seção, julgado em 22/05/2002, DJ 29/05/2002, p. 135. Disponível em: < http://www.stj.jus.br/docs_internet/SumulasSTJ.pdf >. Acesso em: 4 abr. 2018. 
precedentes originários reconhecem a legalidade da execução da pena antes mesmo do trânsito em julgado, após o acórdão condenatório na segunda instância ${ }^{86}$.

Nesta perspectiva, a Constituição, pela sua natureza textual, carrega consigo a latente ameaça de permitir diversas e sucessivas interpretações, conforme sua magnitude semântica (ilimitada). Por outro lado, por ser um texto constitucional, um corpus interpretativo especial, deve prever mecanismos que permitam apenas as interpretações que a sua estratégia previu ou legitimamente aceita. Por conseguinte, o leitor da Constituição terá que decidir onde bloquear e onde estender o "processo de interpretabilidade ilimitada" 87.

Quais os topics possíveis a orientar a leitura do princípio postulado no inciso LVII do art. $5^{\circ}$ da CF/88? Não parece estar em causa o fato de que a culpabilidade só se define após o trânsito em julgado. Assim, podemos perguntar, por exemplo: “a Constituição pretende uma simples enunciação (formal) de não-culpabilidade?”; “quais os efeitos práticos pretendidos com a situação de não-culpabilidade?"; “qual o principal e peculiar efeito da definição de culpabilidade?"; “no contexto normativo-constitucional, o que quer dizer não-culpado?” E então, sob o topic delimitado, o leitor-intérprete poderá direcionar, "orientar a direção das atualizações" que o texto possibilita, considerando não só os limites como as suas condições de coerência $^{88}$.

De fato, a Constituição ou qualquer outro texto, traz sempre latente a ameaça utilitarista do que o seu leitor pretende fazer com ele. Mas este uso, em tese niilista, para a sua configuração, depende também do fim a que pretende encerrar o próprio texto e, por outro, estaria também limitado entre fins legitimáveis e não-legitimáveis:

A configuração do Autor-Modelo depende de traços textuais, mas põe em jogo o universo do que está atrás do texto, atrás do destinatário e provavelmente diante do texto e do processo de cooperação (no sentido de que depende da pergunta: "Que quero fazer com este texto?") ${ }^{89}$.

O leitor-intérprete está na posição de implicar outros sentidos, implícitos, pressupostos, que não apenas aqueles expressamente declarados pela literalidade do texto, mas é preciso

${ }^{86}$ Cf BRASIL. Superior Tribunal de Justiça. Habeas Corpus $n^{\circ} 9.355 / R J$. Sexta Turma, Rel. Ministro Fernando Gonçalves. Brasília, DF, julgado em 18/11/1999, DJ 17/12/1999, p. 401, HC 9355/RJ. Disponível em: < https://goo.gl/Cy6hMn >. Acesso em: 30 mar. 2018.

${ }^{87}$ Cf. ECO, Umberto. Lector in fabula: a cooperação interpretativa nos textos narrativos. São Paulo: Perspectiva, 2011. p. 70.

${ }^{88}$ Cf. ECO, Umberto. Lector in fabula: a cooperação interpretativa nos textos narrativos. São Paulo: Perspectiva, 2011. p. 71-72.

89 ECO, Umberto. Lector in fabula: a cooperação interpretativa nos textos narrativos. São Paulo: Perspectiva, 2011. p. 49. 
considerar as condições em que este destinatário, ainda que seja o STF, está "co-textualmente autorizado" a colaborar na atualização do "que pode atualmente subsistir apenas no co-texto, mas que virtualmente já subsistia no semema". Em suma, é preciso que as condições do texto "autorize co-textualmente" o autor a encontrar os sentidos que virtualmente estão presentes no texto ${ }^{90}$. Consequentemente, o topic, enquanto fenômeno pragmático, permite que se estabeleça um certo nível de sentido, quer dizer, orienta as escolhas do leitor-intérprete, de modo a estabelecer o nível de coerência interpretativa do texto.

Portanto, não só é preciso que se estabeleça o topic definidor do sentido interpretativo do princípio constitucional previsto no art. $5^{\circ}$, LVII, da CF/88: a declaração de não-culpabilidade justifica ou não o início de execução da pena? Mas também é fundamental que se aplique uma interpretação sistemática do ordenamento. Neste sentido, se a Constituição permite a execução da pena antes mesmo do trânsito em julgado da sentença, consequentemente, os arts. 283 do CPP e 105, 107 da LEP, por exemplo, são inconstitucionais na forma textual que hoje apresentam e precisam do ajuste de sua conformidade ou invalidação; do contrário, se tais dispositivos infraconstitucionais são irrepreensíveis na constitucionalidade do texto que apresentam, então, o princípio de não-culpabilidade é incompatível com o início de execução da pena antes do trânsito em julgado da sentença condenatória.

Tome-se por exemplo o texto do art. 283 do CPP:

Ninguém poderá ser preso senão em flagrante delito ou por ordem escrita e fundamentada da autoridade judiciária competente, em decorrência de sentença condenatória transitada em julgado ou, no curso da investigação ou do processo, em virtude de prisão temporária ou prisão preventiva (grifou-se) ${ }^{91}$.

Em confronto com princípio constitucional de que "ninguém será considerado culpado até o trânsito em julgado de sentença penal condenatória", nenhum dos dois, conforme o texto que apresentam, releva na forma textual (literal) qualquer sinal de incompatibilidade. Todavia, a partir da interpretação que se adotou no HC 126.292, constata-se uma antinomia interpretativa, posto que o dispositivo do CPP, delimitado o topic no âmbito do Direito Penal, e isto é relevante porque o seu texto, por exemplo, não tem em perspectiva a prisão administrativa, proíbe categoricamente qualquer outro tipo de prisão, no campo penal, repete-

${ }^{90}$ Cf. ECO, Umberto. Lector in fabula: a cooperação interpretativa nos textos narrativos. São Paulo: Perspectiva, 2011. p. 7.

${ }^{91}$ BRASIL. Decreto-Lei n 3.869 de 3 de outubro de 1941. Código de Processo Penal. In: Diário Oficial da República Federativa do Brasil, Brasília, DF, 13 out. 1941. Disponível em: < http://www.planalto.gov.br/ccivil_03/decreto-lei/Del3689Compilado.htm >. Acesso em: 31 mar. 2018. 
se, que não seja após o trânsito em julgado ou de natureza cautelar, neste caso, no curso da investigação ou do processo.

Portanto, face ao próprio texto do diploma processual, o argumento de que o dispositivo, ao explicitar a prisão temporária e a preventiva, implicitamente legitima a prisão em segunda instância ${ }^{92}$, está desnutrido de fundamentação argumentativa porque, não se ignorando a comunidade jurídica e o possível auditório a quem se dirige, a enciclopédia processual prevê claramente a diferença entre a prisão de natureza cautelar e a prisão (definitiva) para o cumprimento de sentença penal condenatória.

Em princípio, o problema da antinomia se resolve pelo critério hierárquico, ou seja, sendo a Constituição a lex superior, ela prevalece face ao texto da norma infraconstitucional ${ }^{93}$. 0 ponto é que não figura, na interpretação literal do texto de nenhuma das normas, qualquer contrariedade, a questão só é relevante a partir do entendimento de que não há proibição constitucional ao início da execução da pena antes do trânsito em julgado que, ao menos prima facie, contrasta com a interpretação que pretendeu-lhe conferir a norma processual penal ordinária. Assim, mesmo consciente da diferença do âmbito de validade do princípio constitucional com relação às normas infraconstitucionais, a interpretação que se der ao preceito deverá conformar-se à congruência do sistema.

\section{CONCLUSÃO}

Não se trata de pautar o sentido da Constituição por intermédio de normas infraconstitucionais, mas sim a busca de um sentido coerente com todo o sistema, de forma que a aplicação de uma norma vigente e constitucionalmente válida não possa se concretizar à revelia da interpretação constitucional estabelecida. No mais, o texto do art. 283 do CPP, por exemplo, não é apenas uma regra de conduta, definindo as hipóteses em que se permite a prisão no âmbito penal. Ela constitui também uma norma interpretativa, na medida em que o seu teor,

${ }^{92}$ Cf. Voto do Ministro Barroso na ADC 44. BRASIL. Supremo Tribunal Federal. Medida Cautelar na Ação Declaratória de Constitucionalidade 44 DF. Tribunal Pleno, Rel. Min. Marco Aurélio. Brasília, DF, ATA 23/2018, divulgado 6 mar. 2018, DJe 43, publicado 7 mar. 2018, ADC 44 - MC. Inteiro Teor do Acórdão (Medida Cautelar). Disponível em:

http://www.stf.jus.br/portal/processo/verProcessoPeca. asp?id=313832408\&tipoApp=.pdf >. Acesso em: 30 mar. 2018. p. 63.

${ }_{93}$ Cf. BOBBIO, Norberto. Teoria do ordenamento jurídico. Trad. de Maria Celeste C. J. Santos. 6. ed. Brasília: Universidade de Brasília, 1995. p. 95 
visto na integridade do sistema e levando-se em conta seu âmbito temporal de validade, interpreta, atualiza e busca concretizar o princípio postulado no inciso LVII do art. $5^{\circ}$ da CF/88.

É inegável que o princípio declarado no art. $5^{\circ}$, LVII, da CF/88, não fala explicitamente em "inocência", "cumprimento de pena" ou mesmo "prisão", mas deve-se ter em conta que o art. 283 do CPP é um interpretante desse dispositivo constitucional, cujo ato interpretativo, pode-se afirmar, decorre diretamente do Poder Legislativo e que, ao menos em princípio, não apresenta qualquer sinal de contrariedade constitucional.

Deste modo, uma vez que a interpretação constitucional deve ser sempre sistemática, considerando o corpus normativo na sua integralidade, o sentido que se pretenda conferir ao princípio constitucional da presunção de não-culpabilidade não pode razoavelmente ignorar a interpretação dada por esse preceito processual (ao princípio da Constituição), sob pena de se caracterizar como uma pragmática "infeliz" da Constituição.

À vista do quanto previsto na CF/88 acerca da competência do Supremo Tribunal Federal, enquanto guardião da Constituição, não parece haver dúvida quanto ao poder que lhe é conferido para interpretar a Constituição e controlar a constitucionalidade das demais normas infraconstitucionais. Neste sentido, o STF tem a função precípua de atualizar o significado constitucional, no momento de sua aplicação, conforme as adaptações requeridas em decorrência da mudança do tempo e dos costumes. Por esta ótica, o entendimento firmado no HC 126.292 não é um simples absurdo, mas tem alguma razão de ser. Tanto é que aconteceu.

Todavia, apesar do texto constitucional ser um mecanismo preguiçoso, ou seja, diz menos do que deveria dizer, abrindo espaços a serem preenchidos de significados pelo intérprete, é preciso a sensibilidade necessária para se distinguir entre interpretar um texto e usar um texto. No segundo caso, a leitura é legitimável porque feita ao bel-prazer do intérprete, que utiliza o texto para satisfazer sua própria vontade e, portanto, tudo é possível, mesmo que pretenda ler Shakespeare como se fosse James Joyce. Os fins justificam os meios porque, ao usar um texto, o que está em jogo é a própria satisfação pessoal do leitor.

Por sua vez, a leitura da Constituição, enquanto texto público, cuja autoridade de sua criação é politicamente justificada e juridicamente reconhecida, em que a sua enciclopédia tem por fixados determinados sentidos do seu texto, amplamente reconhecidos pela comunidade a quem é dirigida, não pode ser feita ao modus de alguém que pretende usar um texto. A leitura da Constituição deve sempre tomar em conta a realçada diferença entre interpretar e ler um texto. E sendo a Constituição, portanto, o que ela mesma representa, não pode ser lida como se fosse um folheto de cordel. 
Em suma, o que a Constituição diz neste momento, conforme as condições atuais da anunciação, ainda que suscetível a uma pragmática do texto, não pode destoar em demasia do que a Constituição quis dizer nas circunstâncias de sua enunciação e dos sentidos que a comunidade majoritariamente the conferiu. O Supremo Tribunal Federal é, sim, o guardião da Constituição, conforme os termos da Lei por ela mesma. Mas o Supremo Tribunal não é proprietário da Constituição nem dos sentidos políticos e jurídicos que decorrem do seu texto.

\section{REFERÊNCIAS}

AGUDELO, Carlos Agudelo. Una respuesta a la 'dificultad contramayoritaria' a partir de las 'virtudes pasivas' de los jueces. Precedente. Anuario Jurídico, California, v. 5, n. 03, p. 181224, jul./dez. 2014.

ASSIS, Machado de. O alienista. In: Obra Completa de Machado de Assis. Vol. I. Rio de Janeiro: Nova Aguilar, 1994.

BOBBIO, Norberto. Teoria do ordenamento jurídico. Trad. de Maria Celeste C. J. Santos. 6. ed. Brasília: Universidade de Brasília, 1995.

BRASIL. Decreto-Lei no 3.869 de 3 de outubro de 1941. Código de Processo Penal. In: Diário Oficial da República Federativa do Brasil, Brasília, DF, 13 out. 1941. Disponível em:

http://www.planalto.gov.br/ccivil_03/decreto-lei/Del3689Compilado.htm . Acesso em: 31 mar. 2018.

BRASIL. Decreto-Lei n 1.002 de 21 de outubro de 1969. Código de Processo Penal Militar. In: Diário Oficial da República Federativa do Brasil, Brasília, DF, 21 out. 1969. Disponível em: http://www.planalto.gov.br/ccivil_03/decreto-lei/Del1002.htm . Acesso em: 31 mar. 2018.

BRASIL. Lei n ${ }^{\circ} 7.210$ de 11 de julho de 1984. Institui a Lei de Execução Penal. In: Diário Oficial da República Federativa do Brasil, Brasília, DF, 13 de jul. 1984. Disponível em: http://www.planalto.gov.br/ccivil_03/leis/l7210.htm . Acesso em: 2 abr. 2018.

BRASIL. Constituição da República Federativa do Brasil, 1988. Disponível em: http://www.planalto.gov.br/ccivil_03/constituicao/constituicaocompilado.htm . Acesso em: 30 mar. 2018.

BRASIL. Lei $n^{\circ} 12.403$ de 4 de maio de 2011. Altera dispositivos do Decreto-Lei $n^{\circ} 3.689$, de 3 de outubro de 1941 - Código de Processo Penal, relativos à prisão processual, fiança, liberdade provisória, demais medidas cautelares, e dá outras providências. n: Diário Oficial da República Federativa do Brasil, Brasília, DF, 5 mai. 2011. Disponível em:

http://www.planalto.gov.br/ccivil_03/_Ato2011-2014/2011/Lei/L12403.htm . Acesso em: 31 mar. 2018. 
BRASIL. Superior Tribunal de Justiça. Súmula no 9. A exigência da prisão provisória, para apelar, não ofende a garantia constitucional da presunção de inocência. Brasília, DF, 1990. STJ, Terceira Seção, julgado em 06/09/1990, DJ 12/09/1990, p. 9278. Disponível em: https://goo.gl/ywbbNK . Acesso em: 4 abr. 2018.

BRASIL. Superior Tribunal de Justiça. Súmula no 267. A interposição de recurso, sem efeito suspensivo, contra decisão condenatória não obsta a expedição de mandado de prisão. [S.l.], 2002. STJ, Terceira Seção, julgado em 22/05/2002, DJ 29/05/2002, p. 135. Disponível em: http://www.stj.jus.br/docs_internet/SumulasSTJ.pdf . Acesso em: 4 abr. 2018.

BRASIL. Superior Tribunal de Justiça. Habeas Corpus no 9.355/RJ. Sexta Turma, Rel. Ministro Fernando Gonçalves. Brasília, DF, julgado em 18/11/1999, DJ 17/12/1999, p. 401, HC 9355/RJ. Disponível em: https://goo.gl/Cy6hMn . Acesso em: 30 mar. 2018.

BRASIL. Supremo Tribunal Federal. Medida Cautelar na Ação Declaratória de Constitucionalidade 44 DF. Tribunal Pleno, Rel. Min. Marco Aurélio. Brasília, DF, ATa 23/2018, divulgado 6 mar. 2018, DJe 43, publicado 7 mar. 2018, ADC 44 - MC. Inteiro Teor do Acórdão (Medida Cautelar). Disponível em: http: //www.stf.jus.br/portal/processo/verProcessoPeca. asp?id=313832408\&tipoApp=.pdf . Acesso em: 30 mar. 2018.

BRASIL. Supremo Tribunal Federal. Repercussão Geral. Tema 925. Plenário Virtual, Rel. Min. Teori Zavascki. Brasília, DF, julgado em 10/11/2016, DJe-251, 25 nov. 2016, ARE 964246 - RG. Disponível em: https://goo.gl/tK6tcX.

BRASIL. Supremo Tribunal Federal. Habeas Corpus $n^{\circ}$ 126.292/SP. Tribunal Pleno, Rel. Min. Teori Zavascki. Brasília, DF, julgado 17 fev. 2016, DJe-100, 17 mai. 2016. Disponível em: http: //portal.stf.jus.br/processos/downloadPeca.asp?id=311159272\&ext=.pdf . Acesso em 30 mar. 2018.

BRASIL. Supremo Tribunal Federal. Habeas Corpus no 84.078/MG. Tribunal Pleno, Rel. Min. Eros Grau. Brasília, DF, DJe-035, julgado em 05 fev. 2009, publicado 26 fev. 2010, Ementário no 2391-5, p. 1048-1213. Disponível em:

http: / / redir.stf.jus.br/paginadorpub/paginador.jsp?docTP=AC\&doclD=608531 . Acesso em 30 mar. 2018.

CAMARGO, Margarida Maria Lacombe. Hermenêutica e argumentação: uma contribuição ao estudo do direito. 3. ed. Rio de Janeiro: Renovar, 2003.

DE GIORGI, Raffaele; FARIA, José Eduardo; CAMPILONGO, Celso. Estado de coisas inconstitucional. Estadão, São Paulo, 19 set. 2015. Opinião. Disponível em: http://opiniao.estadao.com.br/noticias/geral,estado-de-coisas-inconstitucional, 10000000043 . Acesso em: 21 set. 2015.

ECO, Umberto. Conceito de texto. trad. Carla de Queiroz. São Paulo: Universidade de São Paulo, 1984.

ECO, Umberto. Lector in fabula: a cooperação interpretativa nos textos narrativos. Trad. de Attílio Cancian. São Paulo: Perspectiva, 2011. 
FREITAS, Juarez. A interpretação sistemática do direito. 5. ed. São Paulo: Malheiros, 2010.

GIAGOMOLLI, Nereu José. O devido processo penal: abordagem conforme a Constituição Federal e o Pacto de São José da Costa Rica. São Paulo: Atlas, 2014.

LOPES JR., Aury. Direito processual penal. 12. ed. São Paulo: Saraiva, 2015.

MENDES, Gilmar Ferreira. A presunção de não culpabilidade e a orientação do ministro marco aurélio. Marco Aurélio Mello: ciência e consciência. Migalhas, v. 1, p. 33-48, 2015. Disponível em: http://www.migalhas.com.br/arquivos/2016/2/art20160217-09.pdf . Acesso em 4 abr. 2018.

PERELMAN, Chaïm. Ética e direito. Trad. de Ermantina Galvão G. Pereira. São Paulo: Martins Fontes, 1996.

PIMENTEL, Brutus Abel Fratuce. Paul Valéry: estudos filosóficos. 2008. 187 f. Tese (Doutorado em Filosofia) - Faculdade de Filosofia, Letras e Ciências Humanas, Universidade de São Paulo, São Paulo. Disponível em: https://goo.gl/K321Ad . Acesso em: 7 abr. 2018.

ROCHE, John P. Judicial self-restraint. The American Political Science Review, [American Political Science Association, Cambridge University Press], v. 49, n. 3, p. 762-772, 1955. ISSN 0003-0554, 1537-5943. Disponível em: http://www.jstor.org/stable/1951437. Acesso em: 4 abr. 2018.

STRECK, Lenio. Estado de coisas inconstitucional é uma nova forma de ativismo. Conjur, 24 out. 2015. Observatório Constitucional. Disponível em: https://goo.gl/9QwuNh. Acesso em: 30 mar. 2018.

VIEIRA, José Ribas; BEZERRA, Rafael. Estado de coisas fora do lugar (?). Jota, 5 out. 2015. Disponível em: https://www.jota.info/opiniao-e-analise/artigos/estado-de-coisas-fora-lugar05102015\#_ftn6 Acesso em: 10 out. 2015.

VIEIRA, José Ribas; RESENDE, Ranieri Lima. Execução provisória da pena: causa para a corte interamericana de direitos humanos? In: VIEIRA, José Ribas; LACOMBE, Margarida; LEGALE, SIDDHARTA. Jurisdição constitucional e direito constitucional internacional. Belo Horizonte: Forum, 2016. p. 163-177. ISBN 978-85-450-0196-6. Disponível em: https: //ssrn.com/abstract=3223966 . Acesso em 30 ago. 2018.

WALDRON, Jeremy. The core of the case against judicial review. Yale Law Journal, v. 115, n. 6, p. 1346-1406, 2006. 


\section{COMO FAZER REFERÊNCIA AO ARTIGO (ABNT):}

LOIS, Cecília Caballero; TAVARES, Quintino Lopes Castro. Prisão antes do trânsito em julgado: uma pragmática dos sentidos. Revista Eletrônica do Curso de Direito da UFSM, Santa Maria, RS, v. 14, n. 1, e34869, jan./abr. 2019. ISSN 1981-3694. Disponível em: https://periodicos.ufsm.br/revistadireito/article/view/34869 Acesso em: dia mês. ano. doi: http://dx.doi.org/10.5902/1981369434869.

Direitos autorais 2019 Revista Eletrônica do Curso de Direito da UFSM

Editores responsáveis: Rafael Santos de Oliveira e Angela Araujo da Silveira Espindola

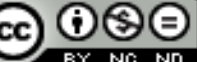

Este obra está licenciado com uma Licença Creative Commons Atribuição-NãoComercial-SemDerivações 4.0 Internacional.

\section{SOBRE OS AUTORES}

\section{CECILIA CABALLERO LOIS}

Possui Graduação em Ciências Jurídicas e Sociais pela Universidade Federal de Santa Maria (1989), mestrado (1993) e doutorado em Direito pela Universidade Federal de Santa Catarina (2001). Realizou estágio pós-doutoral na Pontifícia Universidade Católica do Rio de Janeiro (2009/2010). Foi professora do departamento de direito da Universidade Federal de Santa Catarina (1995/2010), tendo atuado nos cursos de graduação, mestrado e doutorado. Desde 2011, é professora Titular em Filosofia do Direito (DE) da Universidade Federal do Rio de Janeiro, ministrando aulas nos cursos de graduação, mestrado e doutorado. É orientadora de iniciação científica, graduação, mestrado e doutorado. Atua como supervisora de pósdoutorado. Tem experiência na elaboração e coordenação de projetos de colaboração técnica interinstitucionais (PROCAD/CAPES), em projetos voltados à renovação legislativa (PENSANDO O DIREITO/SAL/MJ e CNJ/CAPES) e, ainda, em pesquisas avançadas financiadas por instituições de fomento (UNIVERSAL/CNPq e Prociência/FAPERJ). É bolsista de produtividade (CNPQ/PQ2), desenvolvendo trabalhos sobre filosofia constitucional contemporânea, teoria constitucional e teoria feminista do direito. Atuou junto ao MEC/SESu em processos de avaliação cursos de graduação e pós-graduação na área de Direito. Foi membro, por três mandatos distintos, de Comissão de Ensino do Direito (MEC/SESu) do Ministério da Educação (MEC). É avaliadora ad hoc do comitê de área do direito da CAPES. Coordenou a implantação do Programa de Ações Afirmativas da Universidade Federal de Santa Catarina (2007-2009). É membro do Comitê PIBIC/UFRJ. É coordenadora do grupo de pesquisa Justiça, democracia e assimetrias no direito da Universidade Federal do Rio de Janeiro. Tem experiência na área de Direito Público, Teoria Constitucional, Filosofia do Direito e Gênero, atuando, principalmente, nos seguintes temas: teoria da justiça; teoria da constituição; história do constitucionalismo; filosofia constitucional contemporânea; e, recentemente, epistemologia feminista e teorias feministas do direito. Dedica-se ao estudo de autores como John Rawls; Ronald Dworkin; Charles Taylor; Jurgen Habermas; Michael Walzer; Cass Sunstein; Roberto Gargarella; Chantall Mouffe; Nancy Fraser; Seila Benhabib; Martha C. Nussbaun; entre outros. Atualmente, exerce a função de coordenação do Programa de Pós-Graduação em Direito da Universidade Federal do Rio de Janeiro.

\section{QUINTINO LOPES CASTRO TAVARES}

Professor assistente da Universidade Federal Fluminense, Doutorando em Direito na FND/UFRJ, graduado e mestre em Direito pela UFSC. Tem experiência forense e no magistério superior, com ênfase em Direito Processual e Teoria do Direito, atuando principalmente nos seguintes temas: Direito Processual, Civil e Penal, hermenêutica, constitucional e semiótica textual (aplicada ao Direito). 